\title{
Long-term results after surgical treatment in patients suffering from chronic pancreatitis with signs of biliary hypertension
}

\section{I. Pylypchuk}

SHEI “Ivano-Frankivsk National Medical University”, Ukraine

Key words: hypertension, portal pressure, magnetic resonance cholangiopancreatography, endoscopic retrograde cholangiopancreatography, mechanical jaundice.

\section{Zaporozhye}

medical journal

2018; 20 (5), 660-663

DOI:

10.14739/2310-1210.

2018.5.141629

E-mail:

vipdoz@ukr.net

Ключові слова:

панкреатит,

біміарна гіпертензія,

портальний тиск,

магнітно-

панкреатографія,

ендоскопічна

ретроградна

холангіо-

панкреатографія,

механічна

жовтяниця.

Запорізький

медичний

журнал. - 2018. -

T. 20, № 5(110). -

C. $660-663$ pancreatitis, biliary

резонансна холангіо-

The morbidity of chronic pancreatitis (CP) remains at a high level. Over the past thirty years, more than doubled growth in the number of patients with chronic pancreatitis has been noted.

Objective of our work is to study the long-term results after surgical treatment in patients suffering from CP with signs of biliary hypertension $(\mathrm{BH})$ in order to justify adequate approaches to surgical treatment.

Materials and methods. The long-term results after surgical treatment in 163 patients suffering from $\mathrm{CP}$ with signs of $\mathrm{BH}$ were analyzed. The patients were divided into two groups: the group 1 (main) - $36(22.1 \%)$ patients, who underwent intraoperative monitoring of biliary pressure (IOM BP) for BH diagnostics; the group 2 (comparison group) - 127 (77.9\%) patients, who underwent common methods.

Results. Resection, drainage and palliative operations were performed in patients with $\mathrm{CP}$ and $\mathrm{BH}$ : resection surgeries -95 $(58.3 \%)$ patients; draining surgeries - $44(26.9 \%)$ patients; palliative surgeries - $24(14.8 \%)$ patients. The long-term quality of life study after surgical interventions was conducted in $94(57.6 \%)$ patients. Good results were obtained in $25(89.2 \%)$ patients of the group 1 and in $45(68.2 \%)$ patients of the group 2; satisfactory - in $2(7.1 \%)$ patients of the group 1 and in $17(25.7 \%)$ patients of the group 2; unsatisfactory - in 1 (3.6 \%) patient of the group 1 and in 4 (6.1\%) patients of the group 2.

Conclusions. The proposed comprehensive diagnostic-therapeutic approach using the IOM BP method allowed obtaining good long-term results in $89.2 \%$ of patients in the absence of $\mathrm{BH}$ recurrence. In the group of patients without $\mathrm{BP}$ monitoring the recurrent $\mathrm{BH}$ with mechanical jaundice manifestations appears significantly more often by $15.1 \%\left(X^{2}=4.22, P=0.04\right)$.

\section{Віддалені результати хірургічного мікування хворих на хронічний панкреатит з ознаками біміарної гіпертензії}

\section{В. І. Пилипчук}

Мета роботи - вивчити віддалені результати хірургічного лікування хворих на хронічний панкреатит (ХП) з ознаками біліарної гіпертензії (БГ) для обґрунтування адекватних підходів до хірургічного лікування.

Матеріали та методи. Здійснили аналіз віддалених результатів хірургічного лікування 163 осіб, які хворі на ХП з ознаками БГ. Хворих поділили на дві групи: I (основна) група - 36 (22,1\%) пацієнтів, в яких для діагностики БГ застосували інтраопераційний моніторинг біліарного тиску (ІОМ БТ); II (порівняння) - 127 (77,9 \%) пацієнтів, в яких використали загальноприйняті методи.

Результати. Хворим на ХП із БГ здійснили резекційні, дренувальні та паліативні операції: операції резекційного типу - 95 (58,3 \%) осіб; операції дренувального типу - 44 (26,9\%); паліативні операції - 24 (14,8 \%). Якість життя у віддалені строки після оперативних втручань вивчили у 94 (57,6 \%) осіб. Добрі результати отримали у 25 (89,2 \%) пацієнтів I групи та 45 (68,2\%) пацієнтів II групи, задовільні - 2 (7,1 \%) пацієнтів I групи та 17 (25,7 \%) пацієнтів II групи; незадовільні - в 1 (3,6 \%) пацієнта I та 4 (6,1%) пацієнтів II групи.

Висновки. Запропонований комплексний діагностично-лікувальний підхід із використанням методу ІОМ БТ дав можливість отримати добрі віддалені результати у 89,2 \% пацієнтів за відсутності в них рецидиву БГ. У групі пацієнтів без моніторингу БТ рецидив БГ із проявами механічної жовтяниці виникає вірогідно частіше в $15,1 \%\left(x^{2}=4,22, p=0,04\right)$.

Киючевые слова: панкреатит, билиарная гипертензия, портальное Аавление, магнитно-резонансная холангиопанкреатография, энАоскопическая ретроградная холангиопанкреатография, механическая желтуха.

\section{Отдаленные результаты хирургического мечения больных хроническим панкреатитом с признаками билиарной гипертензии}

\section{В. И. Пилипчук}

Цель работы - изучить отдаленные результаты хирургического лечения больных ХП с признаками БГ для обоснования адекватных подходов к хирургическому лечению.

Материалы и методы. Проведен анализ отдаленных результатов хирургического лечения 163 больных ХП с признаками БГ. Больные разделены на две группы: I (основная) группа - $36(22,1 \%)$ пациентов, у которых для диагностики БГ применен интраоперационный мониторинг билиарного давления (ИОМ БТ), II (сравнения) группа - 127 (77,9 \%) пациентов, у которых использованы общепринятые методы.

Результаты. Больным ХП сБГ проведены резекционные, дренирующие и паллиативные операции: операции резекционного типа - 95 (58,3 \%); операции дренирующего типа - 44 (26,9 \%); паллиативные операции - 24 (14,8 \%) пациента. Качество жизни в отдаленные сроки после оперативных вмешательств изучено у 94 (57,6 \%) пациентов. Хорошие результаты получены у 25 (89,2 \%) пациентов I группы и 45 (68,2 \%) пациентов II группы, удовлетворительные - у 2 (7,1 \%) пациентов I группы и 17 (25,7%) пациентов II группы; неудовлетворительные - у 1 (3,6 \%) пациента I и 4 (6,1%) пациентов II группы. 
Выводы. Предложенный комплексный диагностически-лечебный подход с использованием метода ИОМ БТ позволил получить хорошие отдаленные результаты у 89,2 \% пациентов при отсутствии у них рецидива БГ. В группе пациентов без мониторинга БТ рецидив БГ с проявлениями механической желтухи возникает достоверно чаще в $15,1 \%\left(x^{2}=4,22, p=0,04\right)$.

\section{Introduction}

Surgical treatment of $\mathrm{CP}$ is a relevant, complex and not completely solved problem, from 4 to $9 \%$ of patients with $\mathrm{CP}$ need surgical care [1]. The currently available treatment strategies for CP suggest that surgery is the last link, when conservative treatment, lifestyle changes and endoscopic methods have failed [2,3].

$\mathrm{BH}$ in the long term after the operative interventions on CP appears in $25 \%$ of patients after draining operations and in 8-9 \% of patients after resection surgeries [4], and according to some data - even in $30 \%$ [5].

\section{The objective}

The objective of the research is to study the long-term results after surgical treatment in patients suffering from $\mathrm{CP}$ with signs of biliary hypertension $(\mathrm{BH})$ in order to justify adequate approaches to surgical treatment.

\section{Material and methods}

The results analysis of the examination and treatment of 573 patients with $\mathrm{CP}$, including $163(28.4 \%)$ patients with symptoms of $\mathrm{BH}$, was performed. Patients with $\mathrm{CP}$ and $\mathrm{BH}$ were divided into two groups: the group 1 (main) -36 $(22.1 \%)$ patients who underwent the methods proposed by us for $\mathrm{BH}$ diagnosis, in particular IOM BP (prospective period: 2014-2016); the group 2 (comparison group) - 127 (77.9\%) patients, who were examined by common methods for BH diagnosis (retrospective period: 2009-2013). The groups are non-selective and age-, gender- and structure of the disease matched $(P>0.05)$. In both groups of patients the number of men significantly exceeded the number of women: women were 9 (5.5\%), men - $154(94.5 \%)$, aged from 21 to 63 years, the average age was $45.8 \pm 0.8$ years.

For diagnosis of $\mathrm{BH}$ laboratory studies (level of total and direct bilirubin, alkaline phosphatase), ultrasound examination (ultrasonography), endoscopic retrograde cholangiopancreatography (ERCPG), computed tomography $(C T)$, magnetic resonance cholangiopancreatography (MRCP) were used.

The IOM BP method, developed by the author, and the device for $\mathrm{BH}$ diagnostics in the course of surgery on pancreas head were used for the main group patients $[6,7]$. Two goals were pursued: a diagnostic one (intraoperative detection of $\mathrm{BH}$, which was not diagnosed at the preoperative stage) and a tactical one (correction of surgical intervention to eliminate $\mathrm{BH}$ ). Biliary pressure in the common bile duct (CBD) was measured by installing a catheter through the cystic duct stump (with maximum preservation of the biliary system integrity). Using a silicon tube it was connected to a digital manometer, in particular, multifunction single channel control meter "OWEN TRM 201" with a sensor "OWEN PT 100-OP/OVP/VP" (Kharkiv, Ukraine), output port of which was connected to a computer input port. No complications occurred in the course of IOM BP.

There were three degrees of $\mathrm{BH}$ : $\mathrm{BH}$ of the first de- gree - pressure in the CBD was increased from 160 to $190 \mathrm{~mm}$ WG; $\mathrm{BH}$ of the second degree - increase of biliary pressure from 190 to $250 \mathrm{~mm} \mathrm{WG}$; $\mathrm{BH}$ of the third degree pressure in duct invariably exceeds $250 \mathrm{~mm} \mathrm{WG}$.

For the purposes of statistical processing a database was created using Microsoft Excel; the material in it was grouped according to the studied cohorts; statistical calculations were performed using the integrated licensed analysis packages and descriptive statistics in Microsoft Excel 2007 and Statistica 6.0. All the quantitative data received in the study course were first checked for their type according to Kolmohorov-Smirnov and Lilliefors tests. Since the absolute majority of these data corresponded to the normal Gaussian distribution, an arithmetical mean \pm a standard deviation $(\mathrm{M} \pm \mathrm{m})$ were chosen for the central tendency description, while to assess the significance of differences and zero hypothesis verification the parametric Student t-test for dependent and independent samples was used.

Statistical processing of category (qualitative) data was done by calculating the frequency of signs occurrence per 100 examined (\%), while consistency check of the data difference in the experimental groups was done by calculating the $X^{2}$ conformance characteristics.

\section{Results}

Patients, who were performed operations on $\mathrm{CP}$ with signs of $\mathrm{BH}$, were divided into two groups: with IOM BP and without it. The tactics of surgical intervention in patients, who were performed IOM BP, depended on the monitoring results. In particular, if pancreatic head fibrous tissues excision and release of the CBD intrapancreatic part during the resection stage of duodenum-preserving operation contributed to $\mathrm{BH}$ elimination, no intervention was performed on the bile duct. If the $\mathrm{BH}$ remained, the operation was supplemented by intervention on the bile duct.

In patients of the group 2, surgical intervention was performed on the basis of preoperative and intraoperative data on $\mathrm{BH}$, mainly on the presence or absence of bile duct ectasia, emptying of the gallbladder by palpation.

On the basis of the study, a surgical tactics for $\mathrm{CP}$ treatment with $\mathrm{BH}$ correction, which is represented in the form of the following scheme (Fig. 1), was developed.

The following operations were performed for patients with $\mathrm{CP}$ and $\mathrm{BH}$ (Table 1).

Thanks to the operative interventions, $\mathrm{BH}$ was eliminated during the operation in all patients with $\mathrm{CP}$ and $\mathrm{BH}$.

The long-term quality of life study after surgical interventions was conducted in $94(57.6 \%)$ patients: in 28 $(77.7 \%)$ patients in the group 1 and in $66(51.9 \%)$ patients in the group 2. We observed 35 patients (37.2\%) ourselves, using clinical, laboratory and instrumental examinations, and by completing the SF-36 questionnaire. In 26 (27.6\%) patients, the results of surgical treatment were studied on the basis of medical documentation, which was maintained 
Table 1. Operative interventions in patients with $\mathrm{CP}$ and $\mathrm{BH}, \mathrm{n}(\%)$

\begin{tabular}{l|l|l|l|l|}
\hline \multirow{2}{*}{ Operations } & \multicolumn{3}{l}{ Group 1 } & \multicolumn{2}{l}{ Group 2 } \\
\cline { 2 - 6 } & abs. & $\%$ & abs. & $\%$ \\
\hline Frey's procedure & 26 & 72.2 & 46 & 36.2 \\
\hline Pancreaticoduodenal resection (PDR) & - & - & 13 & 10.2 \\
\hline Berne modification of Beger procedure & 4 & 11.1 & 3 & 2.3 \\
\hline Longitudinal pancreatoenterostomy (LPES) with HJA & 2 & 5.5 & 29 & 22.8 \\
\hline Cystoenterotomy (CET) & - & - & 1 & 0.8 \\
CET + HJA & 1 & 2.8 & 5 & 3.9 \\
\hline CPES & 1 & 2.8 & 3 & 2.3 \\
\hline Endoscopic cystoduodenostomy & - & - & 2 & 1.6 \\
\hline HJA & - & - & 19 & 14.9 \\
\hline Enucleation of the PG cyst & 2 & 5.5 & 1 & 0.8 \\
\hline ERCP with choledocholithextraction & - & - & 2 & 1.6 \\
\hline ERCP with stenting & - & - & 3 & 2.3 \\
\hline
\end{tabular}

Table 2. Evaluation of the results of surgeries for patients with $\mathrm{CP}$ and $\mathrm{BH}$ in the long-term postoperative period, $\mathrm{n}(\%)$

\begin{tabular}{|c|c|c|c|c|c|}
\hline \multirow[t]{2}{*}{ Result } & \multicolumn{2}{|c|}{ Group $1(n=28)$} & \multicolumn{2}{|c|}{ Group $2(n=66)$} & \multirow[t]{2}{*}{$\mathbf{P}$} \\
\hline & abs. & $\%$ & abs. & $\%$ & \\
\hline Good & 25 & 89.2 & 45 & 68.2 & $>0.05$ \\
\hline Satisfactory & 2 & 7.1 & 17 & 25.7 & $>0.05$ \\
\hline Unsatisfactory & 1 & 3.6 & 4 & 6.1 & $>0.05$ \\
\hline
\end{tabular}

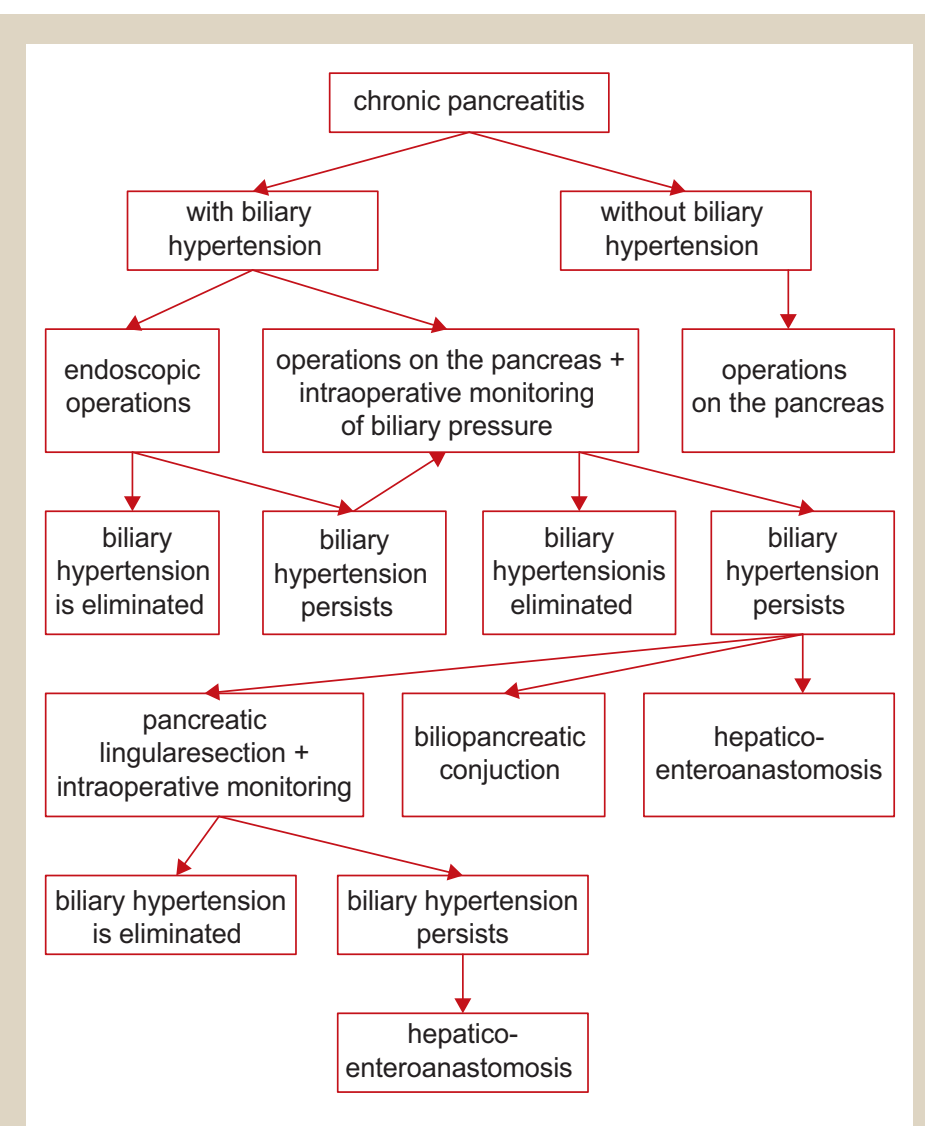

Fig. 1. Scheme of surgical treatment for patients with $\mathrm{CP}$ and $\mathrm{BH}$.

by surgeons and gastroenterologists in the patients' areas of residence. In 33 (35.2 \%) patients, the long term postoperative results were evaluated only on the basis of the SF-36 questionnaires completion sent to them.
Indicators of good results were: no evidence of clinical and laboratory signs and instrumental methods of examination data on $\mathrm{BH}$ recurrence; absence of the abdominal pain syndrome that occurred before the surgery; almost the same indicators of the exocrine and endocrine functions of the pancreatic gland (PG) as before surgery or even better; absence of CP complications, which were indications for a surgery. That was possible to obtain in 25 $(89.2 \%)$ patients of the group 1 and only in $45(68.2 \%)$ patients of the group 2, despite the difference between the groups was not statistically significant $(P>0.05)$. In particular, good results were obtained in $47(83.9 \%)$ patients, who were performed Frey's procedure, in 2 (66.6\%) patients after the Berne modification of Beger procedure, in $4(66.6 \%)$ patients operated on cystic formations of PG, in $11(73.4 \%)$ patients after CPES with HJA and only in 5 $(62.5 \%)$ patients after PDR.

The long-term results were evaluated as satisfactory if $\mathrm{BH}$ did not need surgical correction. This was reached in $2(7.1 \%)$ patients of the group 1 and in $17(25.7 \%)$ patients of the group 2 (the difference between the groups was statistically insignificant $(P>0.05)$ ). In particular, satisfactory results were obtained in $7(12.5 \%)$ patients after Frey's procedure, in 4 (26.6 \%) patients after CPES with HJA, in 2 (25.0\%) patients after PDR, in 3 (75.0\%) patients after palliative HJA and in half of patients after ERCP with endobiliary stenting.

The result was considered unsatisfactory if the recurrence of $\mathrm{BH}$ needed surgical intervention. In the group 1, unsatisfactory result was in $1(3.6 \%)$ patient, in the group 2 - in $4(6.1 \%)$ patients.

Distribution of both groups patients by the obtained long-term results is the following (Table 2).

The data of the table indicate the better long-term results in patients who underwent BP monitoring. However, the difference between the indicators is not statistically significant $\left(X^{2}=4.8, P=0.09\right)$.

The statistical analysis showed no significant difference in the overall long-term results between the groups $\left(X^{2}=4.8\right.$, $P=0.09)$. However, the study of $B H$ recurrences in the longterm postoperative period revealed no recurrence of $\mathrm{BH}$ in patients who underwent IOM BP, whereas in the group without $\mathrm{BP}$ monitoring the $\mathrm{BH}$ recurrence was diagnosed in $10(15.1 \%)$ patients. Manifestations of $\mathrm{BH}$ in the long-term postoperative period were after: Frey's procedure - in 5 patients, Berne modification - in 1, CPES with HJA - in 1, HJA - in 1, CEA - in 2 patients.

Thus, it has been found that there was a significant difference between the groups in terms of indicators that characterized the development of $\mathrm{BH}$ recurrence of in the long-term postoperative period $\left(X^{2}=4.22, P=0.04\right)$. This allows us to recommend the developed IOM BP method for the broad application in clinical practice.

During the different terms after the surgery 3 patients died (after Frey's procedure (1), after PDR (1) and after HJA (1)). In one female patient after the PDR severe exocrine insufficiency symptoms requiring repeated inpatient and outpatient treatment were rapidly progressive, in the other two patients the cause of lethal outcome was the liver cirrhosis and liver failure progression.

Statistical analysis of quality of life indicators in patients with $\mathrm{CP}$ and $\mathrm{BH}$ in the long-term postoperative period 
showed that they were significantly better than preoperative ones $(P<0.05)$. However, there was no significant difference in the quality of life between patients groups in the long-term period after the operation $(P>0.05)$.

Depending on the performed operation in patients, the following results of physical (PHs) and psychological $(\mathrm{MHs})$ health in the long-term period were received (Fig. 2).

\section{Discussion}

Thus, the treatment of patients with $\mathrm{CP}$ and signs of $\mathrm{BH}$ should be based on the data of complex examination using modern specific methods of examination, which allows making the correct diagnosis and the optimal surgical treatment tactics determination. All of this can be provided in specialized centers using a multidisciplinary approach that could significantly improve the long-term results of patient's care.

\section{Conclusions}

Consequently, the proposed comprehensive diagnostic-therapeutic approach using the IOM BP method allows obtaining good long-term results in $89.2 \%$ of patients without $\mathrm{BH}$ recurrence.

The long-term results of treatment study in the study group patients and the comparison group shows that the long-term results in the postoperative period in the patients group without BP monitoring do not differ $\left(X^{2}=4.8\right.$, $\mathrm{P}=0.09$ ), but the recurrent $\mathrm{BH}$ with manifestations of mechanical jaundice is significantly more frequent by $15.1 \%$ $\left(X^{2}=4.22, P=0.04\right)$.

Further research prospects. Disadvantages of modern approaches to $\mathrm{CP}$ with $\mathrm{BH}$ surgical treatment could be eliminated, applying fundamentally new approaches to preoperative diagnostics, perioperative management and surgical tactics.

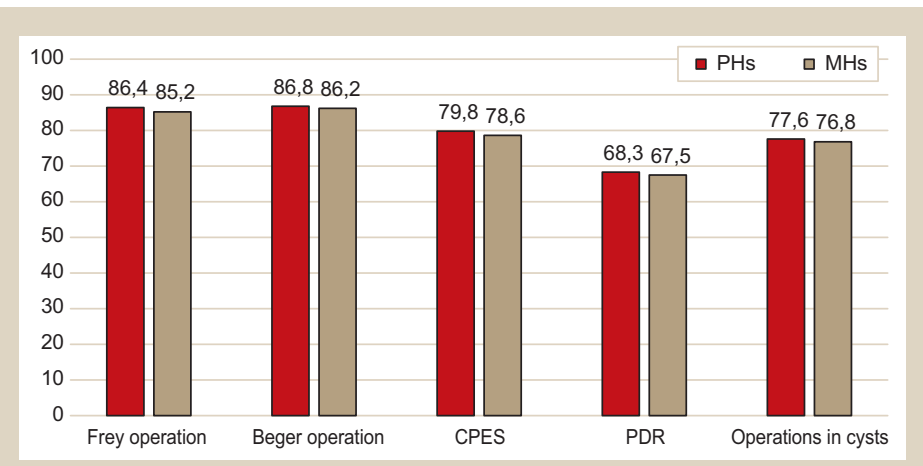

Fig. 2. Indicators of physical (PHs) and psychological (MHs) health in patients with $\mathrm{CP}$ and $\mathrm{BH}$.

\section{References}

[1] Kopchak, V. M., Kopchak, L. A., Pererva, L. A., \& Duvalko, A. V. (2012) Khirurgicheskoe lechenie khronicheskogo pankreatita [Surgical treatment of chronic pancreatitis]. Zdorov'a Ukrainy, 18-19. [in Russian].

[2] Yang C., Bliss L., Freedman S., Sheth, S., Chau Ng, S., Kent, T., et al. (2014). A single-center analysis of surgical treatment for chronic pacreatitis: relatively rare and unevenly deployed. Pancreatology, 14(3), 1, S40. doi: 10.1016/j.pan.2014.05.513.

[3] D'Haese, J. G., Cahen, D. L., \& Werner, J. (2016). Current surgical treatment options in chronic pancreatitis. Pancreapedia: Exocrine Pancreas Knowledge Base. doi: 10.3998/panc.2016.26.

[4] Strate, T., Taherpour, Z., Bloechle, C., Mann, O., Bruhn, J. P., Schneider, C., et al. (2005). Long-term follow-up of a randomized trial comparing the Beger and Frey procedures for patients suffering from chronic pancreatitis. Annals of Surgery, 241, 591-598. doi: 10.1097/01. sla.0000157268.78543.03.

[5] Ho, H. S., \& Frey, C. F. (2001). The Frey procedure: local resection of pancreatic head combined with lateral pancreaticojejunostomy. Archive Surgery, 136(12), 1353-1358. doi: 10.1001/archsurg.136.12.1353.

[6] Pylypchuk, V. I., Kopchak, V. M., \& Shevchuk, I. M. (2015) Patent №101713 Ukraina, MPK A 61V 17/00. Sposib khirurhichnoho likuvannia khronichnoho pankreatytu, uskladnenoho zhovchnokam'ianoiu khvoroboiu [Patent №101713 Ukraine, IPC A 61B 17/00. Method of surgical treatment of chronic pancreatitis complicated with cholelithiasis]. Biulleten, 18. [in Ukrainian].

[7] Pylypchuk, V. I., Kopchak, V. M., \& Shevchuk, I. M. (2016) Patent №109547 Україна, МПК А 61В 17/00 [Patent №109547 Ukraine, IPC A 61B 17/00, №2016 02279. Method of measuring the pressure in the common bile duct].; Biulleten, 16. [in Ukrainian].

The financial resources used to carry out the work: funds of the SHEI "Ivano-Frankivsk National Medical University".

Conflicts of Interest: author has no conflict of interest to declare. Конфмікт інтересів: віАсутній.

Information about author:

Pylypchuk V. I., MD, PhD, DSc, Professor of the Department of Surgery № 2 and Cardiac Surgery, Ivano-Frankivsk National Medical University, Ukraine.

Відомості про автора:

Пикипчук В. І., А-р меА. наук, професор каф. хірургї № 2

та кардіохірургії, АВНЗ «вано-Франківський національний медичний університет», Україна.

Сведения об авторе:

Пилипчук В. И., А-р меА. наук, профессор каф. хирургии № 2 и карАиохирургии, ГВУЗ “Ивано-Франковский национальный медицинский университет", Украина. 